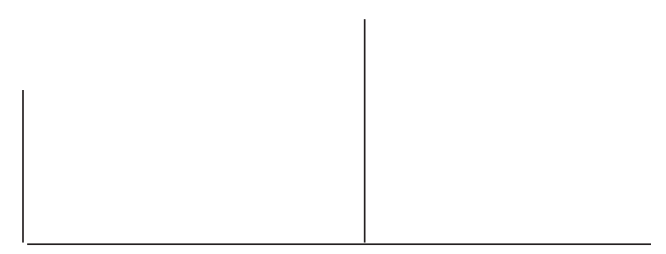

Rev. Latinoam. Psicopat. Fund., V, 2, 56-77

\title{
M de Mãe' e de Morte: dúvidas de amor, certeza da morte
}

\author{
Fátima Regina Flórido Cesar de Alencastro Graça
}

\begin{abstract}
O presente artigo relata a história de um atendimento (com encontros e desencontros) a uma paciente chamada Clara, com intensas dores relacionadas ao câncer do qual era portadora e aos fantasmas que vinha "arrastando desde a infância".

A interrogação sobre a técnica como modo "necessário e justo" de se aproximar do sofrimento e promover mudança atravessa todo o texto.
\end{abstract}

Palavras-chave: Depressão materna, narcisismo de morte, transferência, técnica

1. Primeiro ato falho do texto: ia escrever "M de amor" no lugar de "M de mãe". 
Iniciei mil vezes o diálogo. Não há jeito.

Tenho me fatigado tanto todos os dias vestindo, despindo e arrastando amor

infância, sóis e sombras.

(Hilda Hilst)

Cessar de existir é íngreme.

Minha alegria ficou sem voz.

(Barros, 1996, p. 33)

Esta é uma história de limites e (im)possibilidades. De tristezas e desencontros. Muitas interrogações e escuros... Poderia ter sido diferente? Eu me pergunto desde então...

(É muito cruel quando imaginamos aquele último momento anterior a algum desenlace supondo que poderíamos ter feito isso ou aquilo aquele ato preciso e salvador capaz de mudar o rumo indesejado da história.)

Como começar a falar de Clara? De que modo contar seu estar na vida e no mundo? Que tipo de ensinamentos poderá nos oferecer o seu singular drama - de forma a ajudar-nos a abrir caminho para a mudança e a cura? Como transformar o seu padecimento em saber? ${ }^{2}$

Clara chega a mim tendo sido encaminhada por um psiquiatra, recém-saída de uma depressão e adequadamente medicada. Há dezesseis

2. É uma referência a Fédida, que apresenta o sentido etimológico de "psicopatologia": "um sofrimento que porta em si mesmo a possibilidade de um ensinamento interno" (Fédida, 1981, p. 29). 


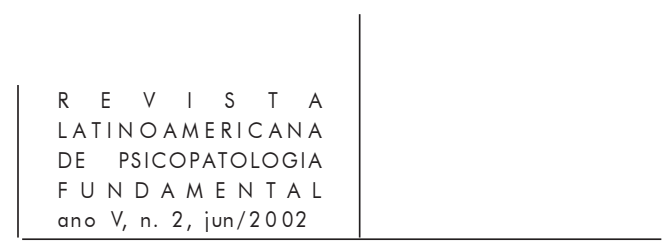

anos apresentava um câncer iniciado no seio, logo após o nascimento de sua segunda filha. No ano anterior perdera o pai, este também com câncer; quinze dias depois, morreu a mãe - são esses acontecimentos que desencadearam a recente crise depressiva.

O pedido de psicoterapia é da própria Clara: ela quer ter alguém com "quem conversar".

Desde o início, em todas as sessões, dois temas principais estavam presentes: seus sentimentos em relação ao câncer e suas lembranças da mãe. Sentia-se responsável pela doença e isso a atormentava muito: "Eu é quem fiz o câncer". "Eu que tenho tanta força para lutar contra, por que não o faço terminar?" "Eu sou malandra, eu tenho esse câncer pra chamar atenção".

Quando Clara me procurou, começava a recuperar-se de uma fase muito difícil de sua doença (estava inclusive sem cabelos). No ano anterior, no mesmo período em que perdera os pais, ficara muito doente.

O início da análise coincidiu com o término das sessões de quimioterapia. Dos seios, o câncer foi para a pele, dali para os ossos. Ainda hoje é preciso tomar regularmente uma injeção para tentar controlar a osteoporose. Nessas ocasiões, fica muito angustiada, tanto por entrar em contato com outros doentes como também pelos efeitos físicos (queda de pressão e tremedeira intensa). Além disso, usa um aparelhinho chamado "porta-cat", que, colocado próximo à virilha por intervenção cirúrgica, injeta diretamente na corrente sangüínea a medicação necessária. Eventualmente, ele sai do lugar e Clara precisa submeter-se a nova cirurgia. Isso tudo a faz sofrer muito, e embora os médicos se mostrem razoavelmente satisfeitos com seu estado físico, ela se sente muito desanimada e desesperançada. Raramente faz esses e outros exames acompanhada, muitas vezes insiste em dirigir, apesar da proibição médica.

$\mathrm{Na}$ verdade, diz que não confia nos médicos: "Eles não sabem nada. Em relação às doenças que não matam, tudo bem; mas câncer...". Apenas procura os médicos quando não tem outro jeito. Recebe os resultados dos exames e demora uma semana para mostrá-los.

\section{Praga de mãe pega?}

Sobre o pai, quase não falava.

Da mãe, me contava de suas exigências e críticas inclementes, de sua "mão de ferro" cuidando dos filhos. Um ressentimento muito intenso a fazia chorar e experimentar uma tristeza enorme: "... a mãe a chamava de burra, feia, incompetente, não servia para nada, não iria se casar!". Clara me dizia: "Praga de mãe pega!". 


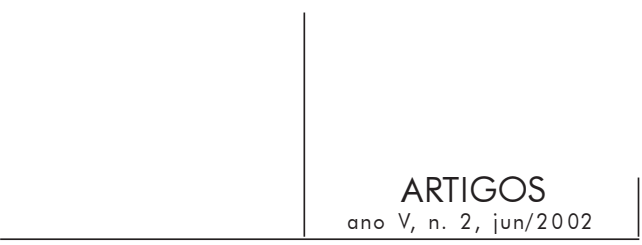

Achava-se mesmo incapaz de casar. Quando, depois dos trinta anos, encontra um companheiro, passa a duvidar constantemente de seu amor. Nutre uma grande mágoa em função de um aborto praticado por pressão dele (que, na época, dizia que não gostava de criança). Logo em seguida, devido à insistência da esposa, ele concorda que ela engravide. Clara pensa que o marido está com ela por pena. Em função do câncer de mama precisou fazer mastectomia. A desconfiança em relação ao amor do marido aumentou. A intimidade dos corpos (sexual) ficou mais difícil - a ponto de não tirar a roupa na frente do parceiro. A angústia relacionada a mostrar o corpo estendeu-se a todos. Não usa roupa sem manga, nem em casa: "Não quero impor essa visão horrível (dos seios mutilados) às pessoas".

No dia-a-dia, está sempre se menosprezando. Diz que é preguiçosa, acorda tarde (às oito horas?!), que não gosta de serviço de casa. Entretanto, é capaz de passar o dia faxinando com "vaporetto", o que, nas suas atuais condições físicas, é absolutamente contra-indicado. Também por ocasião de uma visita de seus sogros, dedicou-se exaustivamente à preparação de pratos requintados, cercandoos de mordomias. Ficou muito cansada e com a certeza terrível de que não gostavam dela e nem reconheciam seu valor.

Apesar de viver sua vida inteira "driblando" uma grande tristeza, Clara é expansiva e alegre "com as outras pessoas", como ela mesma diz.

Vinha de uma família muito pobre do interior, conseguira estudar Belas-artes e agora dava aulas em pequenos grupos, sendo muito respeitada na cidade. Além disso, economizando seu próprio dinheiro ganho nas aulas, regularmente fazia viagens ao exterior para visitar museus, exposições de arte etc.

Uma grande dor

Quando o mar tem mais segredo, não é quando ele se agita, nem quando é tempestade nem quando é ventania.

Quando o mar tem mais segredo, é quando é calmaria. (Sueli Costa/Cacaso)

Clara me mostrava sua grande dor, não ruidosa, mas silenciosa, oculta na vida lá fora. Não era dessas dores que incapacitam ou limitam nosso 


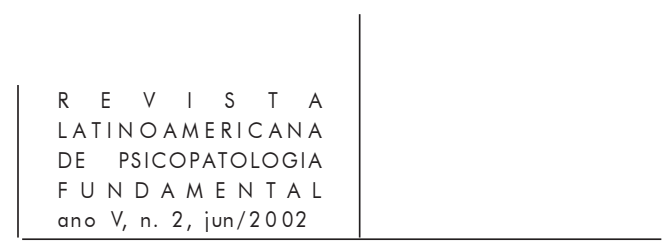

funcionamento no mundo, mas um sofrimento calado, como um mar em calmaria, onde mergulhamos confiantes de sua aparente serenidade e, desatentos, nele afogamo-nos.

Uma tristeza em segredo, quase sobre-humana, que aparecia em toda a sua extensão quando ela estava comigo. Se Clara era evidente (e clara!) em seu desespero, escuros para mim eram os caminhos de sua alma. ${ }^{3}$ Este parece ter sido o grande paradoxo presente do início ao fim de nossa relação: "coração da gente - o escuro, escuros" (Guimarães Rosa ${ }^{4}$ ).

Nossos encontros apresentavam um ritmo específico, num padrão que se repetia: Clara iniciava a sessão com assuntos leves ou dizendo que não tinha o que falar, aos poucos ia se entristecendo e falando com desespero da mãe, do câncer, do marido distante, do futuro incerto das filhas...5 Ao desamor da mãe acresciam-se a desatenção do marido e a incerteza em relação ao afeto das filhas. Dúvidas de amor: Clara saberia que estava "enferma de amor"?

Às vezes me dizia que se piorasse $e^{6}$ muito, já sabia o que ía fazer, "mas não me contaria, porque não era boba". E eu acreditava, temerosa, que tamanha tristeza pudesse mesmo ser atuada.

Chorava muito e quando se aproximava o final do horário, já secando as lágrimas, falava: "Mas tá bom, Fátima...". Era o seu jeito de se refazer, sacudir a grossa poeira e se preparar para retornar ao mundo lá fora. No corredor murmurava algo sozinha: já estava novamente com seus botões...

Sua história me foi sendo relatada aos poucos. Alguma coisa do que eu falava ajudava a trazer à tona recordações e sentimentos.

Meu primeiro movimento em sua direção era de reconhecimento da dor: ela me mostrava sua grande ferida e eu a acolhia.

"Nas trevas do seu coração" eu tentava jogar luz (será que joguei um holofote? Terei desrespeitado a "clareira"?), procurando clarear e dar forma ao escuro de sua dor: dar "uma certa figurabilidade ao enigma" (Figueiredo, 1994, p. 157). De certa forma, eu ansiava por encontrar o foco gerador de tanta desconfiança no amor. Falávamos, então, do profundo desamparo vivido na relação com sua mãe.

Numa de nossas últimas sessões, ela me conta que sua mãe perdera um filho pouco antes de seu nascimento: "Minha mãe achava que era ele que ia nascer de novo. Mas fui eu que nasci. Toda vez que ela me olhava, era ele que ela não via”.

3. Segundo ato falho: no lugar de "caminhos de sua alma", ia escrever "caminhos de sua mãe".

4. Citado por Adélia Prado in Poesia Reunida. São Paulo: Siciliano.

5. Terceiro ato falho: ia escrevendo "futuro incerto da vida".

6. Quarto ato falho (agora da digitadora): em vez de "piorasse muito", "pirasse" muito. 
Clara se via interditada de ser e de nascer, supondo um seqüestro da alma viva da mãe na criança morta. O escuro que eu vivia na relação com Clara, esta vivia com a mãe: buscando decifrar o escuro do coração materno, dava-lhe a temperatura e a consistência do gelo.

Eu acreditava que existia uma relação entre a tristeza que não pôde ser vivida ou manifestada e o câncer. O que deveria ser simbolizado foi para o corpo. Será que a retirada dos seios foi interpretada como um sacrifício-castigo pela transgressão cometida (de gerar a vida)? Como foi vivenciado o nascimento da segunda filha? Como pode dar a vida e o seio, alguém que se viu interditado no seu direito de existir?

Sua história é de tristezas silenciadas. Não se pode falar sobre o câncer em casa. Nunca foram permitidos o choro, o grito, o lamento: "o não acontecimento do não gritar é, em si próprio, uma negação ou expulsão de uma das coisas muito importantes que ligam a psique e o soma; quais sejam, chorar, gritar, berrar, protestar iradamente" (Winnicott, 1964, p. 92).

Também não seria uma história de ódio(s) silenciado(s)?

O ódio de si mesma em Clara junto com "ela (a mãe) me odeia" representavam uma única e mesma indizível unidade no ódio.

É como se Clara falasse: "Desde o dia do meu nascimento, o ódio de minha mãe caiu sobre mim; eu me odeio." Ou, em termos mais elegantes: "Estou sendo perseguida pelas Erínias de uma mãe."” (Stein, 1987, p. 47).

O ódio implodido: o câncer-praga de mãe. Clara-ferida, Clara e sua ferida, Clara e sua mãe-ferida. Seios-pele-ossos. O câncer transita. Dos seios - alimento da vida - à pele, que demarca o dentro e o fora, aos ossos, que deveriam ser a sustentação: muitas possibilidades de se pensar a "via-crucis do corpo"... Ou da alma?

\section{Os escuros, o escuro}

Conversávamos muito. Chegávamos juntas a importantes conclusões a respeito de suas questões existenciais mais básicas. Falávamos de tristezas, do ódio, do desespero, do câncer e de suas terríveis dúvidas sobre o amor do outro - da mãe, do marido, das filhas e agora dos médicos...

7. As Erínias são divindades muito antigas convocadas pela mãe de Édipo (que no poema de Homero se chama Epicasta), após sua morte, para perseguir seu filho. 


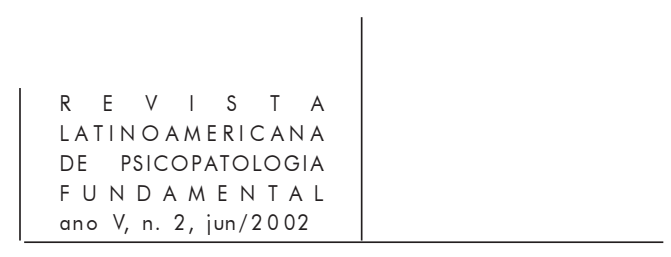

Eu acreditava que nossos encontros estavam sendo muito importantes. Via Clara se apropriando mais e mais de sua história. Novas recordações ajudavamnos a entender melhor seu modo de ser na vida e no mundo. Era uma viagem ao interior de si mesma - de muita profundidade e delicadeza - que trazia alguns pequenos frutos.

Clara se via menos exigente consigo mesma no dia-a-dia. Além disso, conseguira viajar até Nova Iorque, conquista que foi muito valorizada por nós duas. Voltou do passeio satisfeita, pois fora cuidadosa (dificilmente era) em relação a seu estado físico, colocando limites para suas andanças, repousando entre uma saída e outra etc. Sentia-se grata a mim por tê-la ajudado a viajar e me trouxera de presente um marcador de livros comprado no Metropolitan Museum.

Mas logo as pequenas alegrias e conquistas se esmaeciam, a luz que iluminava nossos contatos nos deixava, entrávamos em enevoados caminhos, minha vista se turvava - eu não entendia... Não era sombra nem penumbra, mas densa escuridão.

Minha fala-interpretação tocava Clara. Eu podia sentir: minha "memória da pele" me assinalava! Mas $\log$ o um "afeto tocado, mobilizado, mexido transformava-se no avesso, um desafeto" (Kanaan, 1997): "Mas todo mundo não é assim?", "O que eu faço com isso?", "Mas eu preciso de psicóloga?". Clara me interrogava com freqüência.

Isso acontecia principalmente no final das sessões.

Numa dessas ocasiões, ela me disse que sempre tivera acesso a nossas descobertas (que, portanto, não seriam descobertas!). Eu lhe falei: "De alguma forma você não tinha podido se entristecer, realmente. Não sei exatamente o que acontecia com sua tristeza".

Ela contou, então, que tivera aos dezessete anos um namorado, que eles se amavam muito e que ele morreu saltando com um pára-quedas que não abriu. Sua mãe a proibiu de chorar ou ficar triste e, assim, tinha que ir para a casa de uma amiga para chorar. "Durante anos senti uma tristeza enorme", disse ela, e nesse momento entendi que ela estava me falando de uma tristeza dilacerante que não pôde ser vivida. Fico entre comovida e perplexa com a revelação, para logo em seguida sentir-me impotente. "Mas para que adianta saber disso?". Clara assim me interroga: a vitalidade de nosso encontro era constantemente ameaçada por sua desesperança.

A cada nova sessão, tínhamos que recomeçar tudo: os ganhos eram sempre neutralizados pela sua desconfiança em relação a mim e à vida. As pequenas conquistas eram bombardeadas: "Se eu não me curo do câncer, não vejo mudança que valha a pena". Quando piorava (cansaço, dores), ficava deprimida e faltava. 


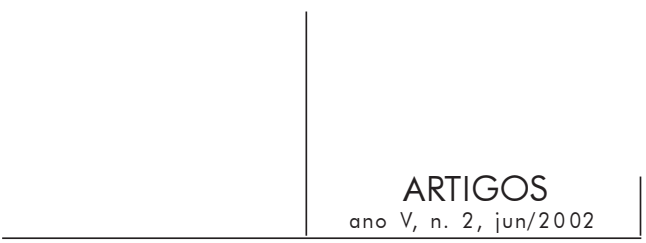

Num nível mais profundo de sua existência, Clara ficou aprisionada num tempo de não-mudança. O câncer, em sua impossibilidade de cura definitiva, serviu para confirmar sua crença de que não há transformação. Sendo assim, nenhuma mudança serve: "Se eu não me curo do câncer, não vejo mudança que valha a pena". A descrença na mudança se relaciona à invariabilidade do humor (deprimido) da mãe. O destino está selado: dentro dos ossos. Ou você ganha o amor da mãe ou nada do que você ganha é significativo e transformador.

Não são poucos os pacientes que não acreditam em mudança. Penso que isso se baseia em suas próprias vivências de não-mudança psíquica. O tempo do sintoma é um tempo de não-mudança. A repetição apenas conduz à permanência da depressão, da angústia ou do vazio. O sofrimento parece nada ensinar.

Vemo-nos então remetidos à experiência primeira da relação com a mãe, ao vazio deixado pela ausência de marcas de uma experiência transformadora.

Segundo Bollas, a mãe é o primeiro objeto transformacional do ambiente interno e externo do bebê. Nesse sentido, a descrença em relação à possibilidade de mudança vincula-se ao fracasso desse primeiro encontro que poderia ter sido transformador.

Quando Clara evita o contato comigo, espera que a tão ansiada mudança estabeleça-se a partir do estado de reclusão. Entretanto, a transformação não é possível porque não houve uma experiência fundante da esperança.

Acredito que a nova matriz das possibilidades de transformação se constituirá no encontro analítico. Num tempo, por vezes demasiado longo, essa matriz será vagarosamente tecida na delicada malha de um afetamento recíproco (analista-paciente). É o primeiro acontecimento - gênese que permite o ingresso na vida: paulatinamente as mudanças começam a acontecer, pululando experiências do novo aqui e ali. O sujeito perde sua impermeabilidade ao mundo, à vida e ao outro. As potencialidades do self são acessadas, em paralelo à processualidade da vida.

Mas era ali, na transferência, que outro (ou o mesmo) grande drama era encenado: a dependência era sempre evitada; todos os esforços se davam no sentido de manter a reclusão. Desconfiança, descrença, desesperança, impediam-na de procurar minha ajuda nos momentos de maior sofrimento. Depender seria estar à mercê de um olhar vazado/esvaziado que, no lugar de refletir - devolvendo o eu ao sujeito, impunha o seu próprio ser, sobrecarregando o filho com sua dor. Clara via no olhar de sua mãe sua própria alma despedaçada e seu filho perdido. ${ }^{8} \mathrm{Um}$ solo de confiabilidade básica ficou faltando. Eu acreditava que este

8. Winnicott, em seu texto "O papel de espelho da mãe e da família no desenvolvimento infantil", diz que o rosto da mãe é o precursor do espelho. "Quando olho, sou visto, logo existo..." 


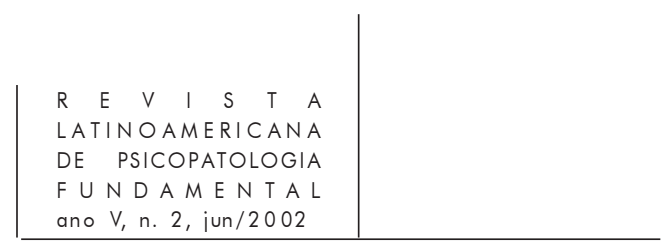

solo pudesse ser constituído na relação comigo. Mas para isso eu precisaria de tempo.

\title{
Entre a necessidade de tempo e a urgência de (sobre)viver
}

\begin{abstract}
A palavra do outro, se oportuna, viva e verdadeira, permite ao destinatário reconstituir seu envelope psíquico continente, e ela o faz na medida em que as palavras ouvidas teçam uma pele simbólica...
\end{abstract}

(Anzieu, 1985, p. 270)

Mas o que eu falava não "colava". A pele tecida por nós duas e que a abrigava por momentos logo se desfazia... É como se eu tivesse estado o tempo todo esticando/ofertando essa "pele comum" que precisamos num momento inicial (ou tardio) da vida, enquanto ela se mantinha longe, reclusa em sua própria pele - como ficava no mundo lá fora, às vezes brilhante, luminosa, inteira (como a pele de seu rosto!), em outros momentos retalhada, em pedaços, ferida (como a pele de seus seios!). Pele impermeável?

Era preciso tempo para que se tecesse uma malha de confiança. Aparentemente, eu me dispunha a esperar. Mas, com certeza, "corríamos atrás do tempo". A sombra de uma urgência estava sempre presente, enevoando, embaralhando meus passos de analista...

Será que - prematuramente - refleti a minha esperança e alegria em um momento em que Clara se via apenas estragada? ${ }^{9}$ Será que impus o reflexo de minha crença na vida, quando ainda ela não sentia que "estar vivo é tudo?" (Winnicott, 1963c, p. 174).

Para que o paciente "queira ser" é preciso que se acolha também o seu nãoser. Será que, apressadamente, não pude esperar o tempo de sua travessia no abismo-deserto da não-existência?

Elsa Oliveira Dias discorre belamente sobre essa questão:

É apenas com a permissão e o suporte para não-ser que o existir pode começar a ser possível. "É apenas da não-existência que a existência pode

(Winnicott, 1967, p. 153). Dessa forma, o olhar da mãe, ao devolver ao bebê o próprio eu, confere-lhe existência. Mas se a mãe reflete a si própria (o seu humor e suas defesas), a percepção toma o lugar da apercepção, do que seria uma troca significativa com o mundo.

9. Nesse sentido, recorro ao relato de M. Little sobre sua análise com Winnicott: "Winnicott dissera sobre mim: 'Sim, você está doente, mas também há muita saúde mental aí - Mas isso fica para depois, o importante agora é a doença” (Little, 1992, p. 50). 


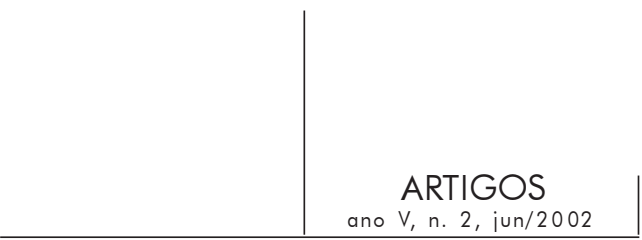

começar", diz Winnicott. Tal como na aceitação e suporte da mãe ao estado de não integração do bebê. Talvez, a falha maior do analista, nesses casos, seja uma incapacidade de suportar (e até de atenuar com) a negatividade que desfaz toda realidade e uma impaciência para introduzir o paciente na existência, na positividade da vida onde as coisas acontecem. A confiabilidade do setting pode ajudar o paciente a querer ser, mas ele precisa confiar em que pode recuar e, de vez em quando, deixar de existir; ele necessita saber que o analista suporta esse retorno à não-existência, ao estado não-integrado, amorfo, da completa dependência. (Dias, 1993, p. 78)

Talvez eu tenha atuado junto a Clara, como outrora ela atuou junto à mãe deprimida: tentando animá-la, tentando trazê-la à vida. Mas nada a comovia no sentido de experimentar a esperança. Será que em um movimento de onipotência tentei impor-lhe a minha alegria, demarcando mais ainda a separação dos mundos (saúde/doença, vida/morte, alegria/tristeza), impedindo-a de ter uma experiência de "pertencimento"? Qual será o lugar do analista junto a pacientes portadores de doença orgânica grave?

Que tipo de vínculo seria possível com Clara, de modo a possibilitar-lhe permanecer e esperar, ajudando-a a experimentar alegria no amor? Com que delicadeza - com que mãos e braços de veludo - deveria ter oferecido um holding para Clara?

Safra, em seu livro Momentos mutativos em psicanálise, apresenta algumas das principais necessidades psíquicas que um "objeto precisaria atender ao indivíduo para que este possa estruturar-se e fazer evoluir a sua personalidade" (1995, p. 115): continência (uma noção bioniana), holding, manipulação especular, apresentação do objeto e interdições. Junto àqueles que ainda não se constituíram, as funções (do analista) mais fundamentais seriam as de holding, continência e especular.

No momento, o que pretendo é destacar a questão do "manejo". Segundo Winnicott, o manejo corresponderia ao conjunto de procedimentos necessários nos casos relatados.

Função extremamente complexa, o holding exige do analista uma atenção especial às necessidades do paciente, um trabalho de identificação dessas necessidades. Isso não é tarefa fácil. Como diz Winnicott:

Uma fonte de equívocos é a idéia de que o termo adaptação às necessidades, no tratamento de pacientes fronteiriços e no cuidado do lactente, significa satisfazer os impulsos do id. Há coisas mais importantes acontecendo e estas são prover apoio aos processos do ego. É somente sob condições de adequação do ego que os impulsos do id, quer satisfeitos ou frustrados, se tornam experiências do indivíduo. (Winnicott, 1963a, p. 217) 


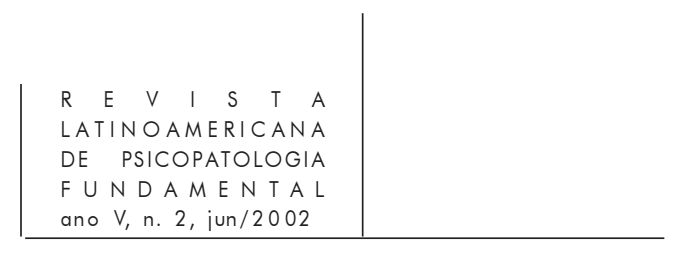

Sustentar o paciente significa, muitas vezes, transmitir em palavras algo que "revele que o analista se dá conta e compreende a profunda ansiedade que o paciente está experimentando" (Winnicott, 1963a, p. 216). Isso implica a (cuidadosa e difícil) identificação da principal questão existencial do sujeito, aquela que diz respeito ao seu verdadeiro self.

Muitos analistas falam do holding como tarefa simples. Entretanto, devemos lembrar que em muitos casos até a manutenção do setting fica ameaçada. Até que o paciente permita ser acolhido, precisamos trabalhar a sua desesperança, desconfiança, seu potencial paranóide. Precisamos sustentar o paciente - como a mãe cuidando do bebê - atentos às suas tendências a se desintegrar, cessar de existir, cair para sempre. Muitas vezes, entretanto, ele se debate em nosso colo, como um bebê que foi atendido um pouco tarde demais. É necessário, então, um tempo de espera, do retorno da confiança e da crença no objeto.

Essas reflexões sobre o manejo, sobre a técnica junto aos pacientes que "moram em móvel mar" são muito importantes. Aqui vale uma digressão. Retirei a expressão "móvel mar" de um poema de Pound. Utilizo-a para referir-me àqueles, exilados na vida e no mundo, que lutam - numa hesitação desesperada - entre a necessidade e o medo de enlouquecer. Olham de fora, carentes do sentimento de pertencer à espécie humana: "Nenhum teto/Protege o navegante ao mar entregue/É o que não sabe o que vai em vida mansa,/Rico e risonho,os pés na terra estável,/Enquanto, meio-morto, mourejando, Eu moro em móvel mar" (Pound, 1985, p. 65).

Acercar-se, chegar perto de um morador sem abrigo na terra firme da confiança no mundo e na vida exige uma aproximação especialmente delicada. O holding requerido não equivale a um debruçar-se desesperado sobre um paciente ou a um disponibilizar-se ilimitadamente. Estar atento e desperto, como sugere Winnicott, implica sim em mãos e braços de veludo; mas que permitam encontros e despedidas. O segurar e sustentar deve possibilitar avanços e recuos por parte do paciente: espaço não apenas para a comunicação; mas ainda para a não-comunicação.

Se, de um lado, Clara com sua dor e com seus atalhos e gambiarras existenciais dificultava nosso encontro; eu posso ter me fixado em alguma posição que me permitia a visão de determinadas necessidades, mas que me tirava do horizonte a percepção de outras.

De que modo nossas limitações se somaram, atrapalhando-se e impossibilitando o estar junto?

Os meus pontos cegos, o meu "afogueado" desejo de curar e animá-la... Como terá Clara lidado com meus excessos - de disponibilidade, de proximidade, de emoção? 


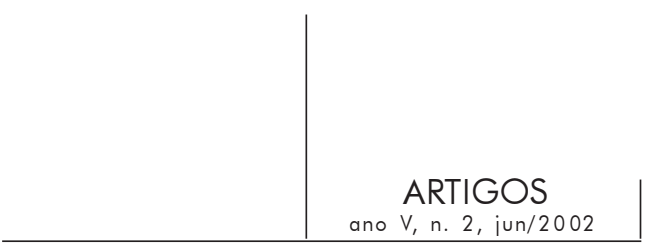

De outro lado, os limites de Clara: seu pavor de depender, sua angústia diante da morte. Terá tido medo de me contaminar com sua tristeza - tal como se sentiu contaminada com a depressão materna? Ou terá temido contaminar seu dia-adia com o sofrimento que lutava desesperadamente para manter restrito aos limites de nossos contatos? Terá tido boas razões para manter os mundos em separado?

Se Clara se defende para não aproximar as partes cindidas é porque só é possível vivê-las em separado, ou seja, não integradas: o psique e o soma, alegria e tristeza, amor e raiva etc. A questão da integração é fundamental aqui. A integração não está garantida desde o início da vida, do ponto de Winnicott, ela é uma conquista. Inicialmente, existe um estado de não-integração a partir do qual a integração acontece - por breves momentos e, só aos poucos, a integração se transforma de fato. A integração depende do cuidado ambiental (holding): o "paradigma dessa função é a forma como a mãe segura o bebê em seus braços" (Safra, 1995, p. 117). A falta desses cuidados leva à vivência de ansiedades terríveis. O cuidado de sustentação transforma essas ansiedades em experiências positivas: "Por outro lado, a desintegração poderá ser vivida como um relaxamento e repouso; cair para sempre passa a ser a alegria no movimento em ser carregado..." (Ibid., p. 118).

À medida que o self se constrói, o bebê torna-se capaz de incorporar lembranças do cuidado ambiental e, portanto, do cuidado de si mesmo. A integração se transforma em um estado cada vez mais confiável, e a desintegração, no lugar da não-integração, passa a ser o negativo da integração.

Pode ser que o bebê esteja sendo segurado pela mãe ansiosa ou angustiada, assim ele não pode relaxar, a não ser por pura exaustão. É interessante pensar que em Clara esse padrão se manteve: consegue relaxar, deita, adormece apenas depois de muito trabalho - depois de grandes faxinas ou de andar muito. Se supormos uma limitada capacidade de holding da mãe Clara; adoecer poderá ter sido o único caminho permitido para tentar alcançar o holding (por meio dos cuidados médicos, familiares e analíticos) não encontrado na mãe. Nesse sentido, a doença teria também esse "objetivo de trazer o tão necessitado cuidado" (Winnicott, 1963b, p. 228).

Um dia, Clara me disse pelo telefone que iria "dar um tempo" (um mês antes das minhas férias), mas não era "esse tempo" que eu queria!... Do meu ponto de vista, isto é uma analista interessada em dar tempo para que esta paciente pudesse encontrar o holding de que precisava, interromper a análise não era exatamente o que eu entendia por "dar um tempo". Ela já vinha falando sobre interromper por conta de dinheiro, e falava desconfiada: “... mas eu preciso de psicóloga?”. Talvez pelo telefone tenha sido mais fácil... 


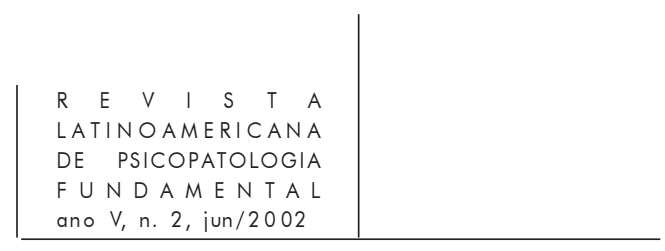

Não retornou. Liguei em fevereiro: depois de falar da falta de dinheiro, Clara me diz que não sente vontade de vir, apesar de precisar muito. "O que aconteceu?", pergunto. "Não dá para contar", ela responde.

Ela diz (é muito sincera, por sinal!) que gosta muito de mim, que eu sou "muito bacana", mas não tem vontade de vir conversar comigo. Acha que é porque não quer "mexer". Conta ainda que naquela tarde havia passado muito mal, mas que agora estava melhor...

\section{É possível encontrar-se a si mesmo sem o outro? ${ }^{10}$}

"Uma mãe costurada por dentro"11 também poderia ser o título dessa história. Com certeza, o papel fundamental da mãe na constituição do psiquismo continua sendo um dos temas principais da minha reflexão, que agora se complexifica: Uma mãe costurada por dentro - em fantasias e projeções - é também uma mãe real.

O reconhecimento da importância do outro-real e da violência por vezes imposta pelo adulto doente à criança foi uma das grandes contribuições de Ferenczi. Nesse sentido, a noção de "bebê sábio" em Ferenczi é muito interessante para a compreensão das crianças que sofreram traumas precoces. Os "sonhos do bebê sábio" seriam aqueles em que pacientes vêem crianças bem pequenas ou bebês falando como adultos, com dizeres profundos, dando palestras etc. (Ferenczi, 1923, p. 214). Em seu importante texto "Análise de crianças com adultos", Ferenczi esclarece o sentido do sonho:

Pois todos nós sabemos que as crianças que muito sofreram, moral e fisicamente, adquirem traços fisionômicos de idade e de sabedoria. Também tendem a cercar maternalmente os outros; manifestamente, estendem assim a outros os conhecimentos adquiridos a duras penas, ao longo do tratamento, sobre o seu próprio sofrimento; tornam-se indivíduos bons e prestimosos. (Ferenczi, 1931, p. 75)

É ainda quando Ferenczi fala de crianças mal-acolhidas (p. 49) que vejo Clara retratada com muita fidelidade: as crianças acolhidas com rudeza e sem carinho ou morrem facilmente ou, se não, conservarão certo pessimismo e aversão à vida - "a sua vontade de viver, viu-se então quebrada" (Idem). O papel

10. É uma pergunta que Green faz no prefácio do livro de Masud Khan, Psicanálise: teoria, técnica e casos clínicos.

11. Refiro-me aqui a um sonho em que meu avô me dizia: “... todos nós temos uma mãe costurada por dentro". 


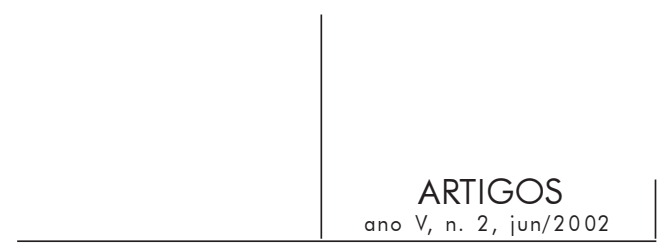

do analista seria então o de introduzir "impulsos positivos da vida e razões para se continuar existindo" (Ibid., p. 50). Winnicott e seus seguidores também se preocuparam com o ambiente.

É mesmo complicado distinguir em Clara o que era a mãe real da que era criação sua. De qualquer maneira, acho que, num primeiro momento, devemos nos relacionar com a dimensão de realidade da violência sofrida e com a dor comunicada.

Entretanto, não seria minha tarefa falar simplesmente como sua mãe a perturbou. De qualquer forma é preciso um período de reconhecimento dos danos sofridos na infância. Lembro-me aqui do relato impressionante de M. Little sobre sua análise com Winnicott, e de como ele falou em certa ocasião: "Como eu odeio sua mãe!".

Tal reconhecimento (do sofrimento) auxilia o paciente a sentir-se mais confiante e a ter acesso às falhas do ambiente. ${ }^{12}$

O final da análise, por sua vez, deve conduzir à realização de que essa mãe é mesmo costurada, "criada" por seu filho. Como Green comenta:

Por mais difícil que tenha sido a vida de uma pessoa, por mais objetivas que tenham sido suas frustrações e decepções, é preciso que, em um momento ou outro, o indivíduo tome consciência de que isto é de sua propriedade. Sua propriedade de transformar os dados de dentro e de fora para criar algo que é seu psiquismo, onde ele cria ao mesmo tempo os outros. Isto não significa, por exemplo, que quando minha paciente fala desse reconhecimento em ter atribuído a sua mãe muitos julgamentos que eram dela, que sua mãe fosse mais normal do que a mãe que apresentara antes [...] Isto não transformava completamente o que já tinha dito sobre sua mãe. Tudo continuava verdadeiro, mas para sua

12. A experiência da raiva é muito significativa nesses casos em que houve falhas ambientais relevantes. Nesse sentido, é muito importante o texto de Winnicott "Aspectos clínicos e metapsicológicos da regressão dentro do setting psicanalítico", onde são apontados os passos da regressão dentro do setting analítico: "Na prática, há uma sequiência de eventos: 1) O fornecimento de um setting que transmita segurança; 2) Regressão do paciente à dependência, com o devido senso do risco envolvido; 3) A sensação, por parte do paciente, de um novo sentido de self, e o self até então oculto, rendendo-se ao ego total. Uma nova progressão dos processos individuais que haviam cessado; 4) Um descongelamento de uma situação de fracasso ambiental; 5) A partir da nova posição de força do ego, a raiva relacionada ao fracasso ambiental inicial, sentida no presente e expressa; 6) Retorno da regressão à dependência, em um progresso ordenado em direção à independência; 7) Necessidades e desejos pulsionais tornando-se realizáveis com uma vitalidade e um vigor genuínos."

No caso de Clara, a raiva aparecia sem que o ego estivesse suficientemente forte para contêla. Clara dizia: "Ah! Mas coitada da minha mãe... eu aqui falando mal dela...”. Terá sido a culpa outro fator importante na interrupção da análise? 


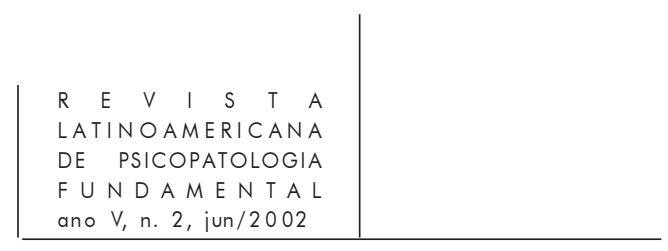

realidade psíquica inconsciente ela é que criava tudo. É isto que Freud e Winnicott dizem quando falam nesses casos difíceis. Winnicott, por exemplo, diz que o importante é que o indivíduo chegue em seu processo de análise a um ponto em que possa considerar todo o seu relato como uma fantasia - porque, efetivamente, esta é a definição de sujeito. Sujeito é o transformador. Sujeito não é uma superfície virgem sobre a qual as coisas vão se imprimindo... Não se faz o que se quer de ninguém... Quando se consegue obter de alguém um falsoself, há sempre por baixo o verdadeiro self, que busca se expressar.

Sartre dizia: "Nós não somos o que fizeram de nós; nós somos o que nós fizemos do que fizeram de nós". Simplesmente que a posição de Sartre era voluntarista e nós, psicanalistas, nos colocamos do ponto de vista da realidade psíquica inconsciente. (Green, 1986, p. 176)

De qualquer maneira, o tempo em que estivemos juntas (eu e Clara) deveria mesmo ser dedicado ao acolhimento do traumático. Mas quais os contornos e os limites de tal acolhimento? Como oferecer um "amor justo" (Fédida, 1981, p. 28), numa justa medida capaz de propiciar a cura?

\section{A depressão materna: o amor gelado}

A depressão da mãe impossibilitou Clara de (aprender a) amar com alegria. Ela vive essa impossibilidade comigo, mas também com as filhas e com o marido. Quando se preocupa com a "herança" (o câncer) que deixa às filhas, a questão que se coloca é: é possível dar a vida a alguém? Lembremos que a doença eclodiu após o nascimento da segunda filha. Dar à luz deve ter sido vivenciado como transgressão - daquela que não tinha direito ao prazer e à vida. Por outro lado, ter filhos não teria sido uma tentativa de se vincular à alegria, à esperança, enfim, à vida?

A depressão da mãe apresenta uma especificidade dramática quando se vincula à morte de um filho. André Green, em seu belo texto "A mãe morta", discorre sobre essa mãe que não estaria morta de fato, mas que permanece viva, porém distante, inanimada. Ali, onde ela deveria ser fonte da vitalidade, da crença, surge tirânica a sua tristeza, o seu desinteresse pelo filho vivo, o seu olhar absorto em seu próprio luto.

Green fala de clínica do vazio, do negativo, de psicose branca, luto branco: um desinvestimento massivo por parte da mãe deixa buracos psíquicos que serão preenchidos por reinvestimentos. Nesse sentido, o ódio que aparece na análise seria secundário a este desinvestimento central do objeto primário. Após a revelação da perda do irmão de Clara, comecei a pensar que o ódio também seria uma tentativa de vincular a mãe a ela, de negar o grande vazio criado pela ausência 


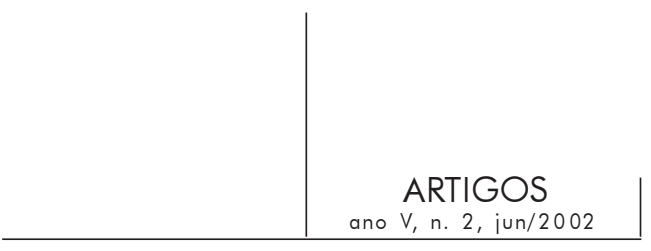

materna. O ódio é um esforço de transformar a mãe morta (devotada a um morto) em uma mãe viva. É esse núcleo vazio/branco que precisará ser abordado na situação de análise - mais que o ódio, pois o que vem primeiro é o amor gelado pelo desinvestimento.

Green diz que no complexo da "mãe morta" o paciente não se apresenta com depressão. No caso de Clara, sua primeira depressão (clínica, poderíamos dizer?) ocorreu quando os pais morreram. Muito interessante a afirmação de Green, pois confirma a minha percepção. Ele vai falar de "depressão de transferência" - a depressão aparece com toda sua força na transferência contrastando com um "comportamento exterior onde a depressão não eclode, pois nada indica que o meio a perceba claramente, o que aliás não impede que as pessoas próximas sofram com as relações objetais que o analisando estabelece com elas" (Green, 1980, p. 255).

Essa depressão será repetição de uma depressão infantil causada não pela separação de um objeto, mas que "se dá na presença de um objeto, ele mesmo absorto num luto" (Idem). O caso mais grave seria o da morte de um filho com pouco tempo de vida.

Em um primeiro momento, a criança vai buscar uma vã reparação da mãe enlutada. Depois serão postos em ação dois tipos de defesa: o desinvestimento da mãe e a identificação inconsciente com a mãe morta. O resultado do primeiro será a constituição de um buraco na trama das relações objetais com a mãe: "o que não impede que os investimentos periféricos sejam mantidos, assim como o luto da mãe modifica sua atitude fundamental com respeito à criança que ela não conseguiu amar, mas que continua a amar, assim como continua a cuidar dela. Todavia, o coração não está presente" (Ibid., p. 257).

Isto seria correspondente ao que eu sinto na contratransferência - ela gosta de mim, sem alegria.

Pela identificação com a mãe, Clara busca possuí-la, tornando-se ela mesma. O câncer pode assim também ser visto como uma metáfora da presença da mãe morta. Se um núcleo gelado se mantém, não há mudança possível.

Green também vai falar sobre um fenômeno psíquico similar ao "bebê sábio" de Ferenczi e à hipertrofia da função mental em Winnicott: "a busca de um sentido perdido estrutura o desenvolvimento precoce das capacidades fantasmáticas e intelectuais do Eu" (Ibid., p. 259). Assiste-se assim a uma obrigação de imaginar, uma obrigação de pensar. Buscando superar o desespero da perda do seio, o sujeito cria um "seio remendado, pedaço de tecido cognitivo destinado a mascarar o buraco do desinvestimento, enquanto que o ódio secundário e a excitação erótica formigam na borda do abismo" (Idem).

Se o sujeito busca compensar intelectualmente ou mesmo artisticamente a perda da mãe, sendo bem-sucedido nessas áreas, no campo das relações 


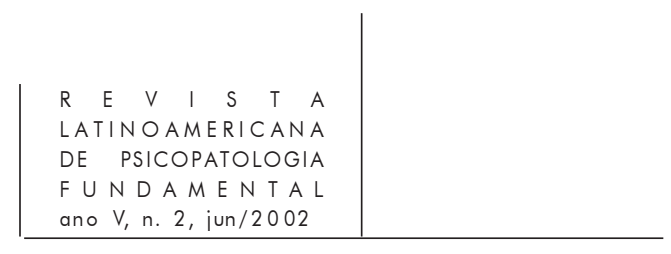

amorosas, grandes dificuldades se mantêm. Se surgem novos objetos, logo, pela presença da mãe morta, a decepção do objeto ou do eu põe fim à experiência. $\mathrm{O}$ centro do Eu esburacado é ocupado pela mãe morta - presença soberana que impede que novos objetos permaneçam. Se a pessoa pensa que o objeto primário não conta mais para ela, que está pronta para novos investimentos, engana-se. Mantém-se assim uma incapacidade de amar, pois o amor continua hipotecado à mãe morta. As palavras de Green confirmam minha percepção de Clara: "O sujeito é rico, mas não pode dar nada de sua generosidade, pois não dispõe de sua riqueza" (Ibid., p. 260).

A frieza que Clara atribuía ao marido é uma nova versão do amor gelado da mãe: "Este núcleo frio queima como gelo e anestesia como ele, mas enquanto for sentido como frio, o amor permanece não disponível" (Ibid., p. 263). A clausura da repetição (o marido, como a mãe, cuida, mas não gosta) deve tê-la impedido de encontrar um amor menos frio. $\mathrm{O}$ amor ardente terá ficado hipotecado, por sua vez, ao namorado morto, visto então como único capaz de derreter o núcleo gelado de seu coração (ardente!).

Sob o domínio da mãe morta, o sujeito vai ter uma necessidade muito grande de autonomia. Ele se aninha, a solidão é procurada. Isso fica bastante claro na relação de Clara comigo: "Eu nunca precisei tanto de você como agora, mas eu quero resolver sozinha". Ela me relata momentos de muito sofrimento - reações adversas à medicação, novas cirurgias, quimioterapia... Depois me conta: "Eu dormi, me cobri, acordei melhor". Esse seu modo de funcionamento, que se repetia da mesma forma a cada situação difícil, sempre me impressionou, porque eu via ali uma busca de aconchego. Clara acorda melhor, mas não há renascimento. Ao despertar, não é a vida que ela re-encontra, mas a sobrevivência.

Num trecho muito bonito, Green fala da recusa da mãe morta a morrer a sua segunda morte:

Muitas vezes o analista diz a si mesmo: "Desta vez foi, ela está morta, a velha, ele (ou ela) vai enfim poder viver e eu respirar um pouco". Um trauma mínimo aparece na transferência ou na vida que dá novamente à imagem materna uma vitalidade, se é que eu posso me expressar assim. É que ela é uma hidra com mil cabeças de quem sempre pensamos ter cortado o pescoço. Só havíamos atingido uma de suas cabeças. Onde é que está o pescoço da besta? (Green, 1980, p. 265)

No caso de Clara, o câncer é mesmo essa hidra atingida aqui, reaparecendo triunfante ali com novas cabeças (as metástases!). 


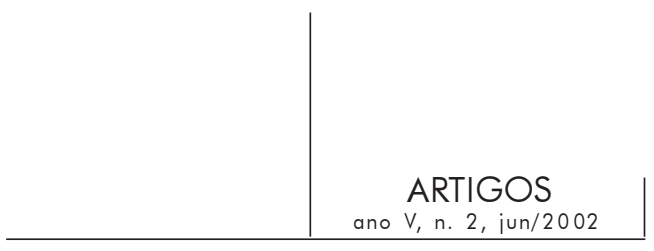

A transferência

Green fala que nesses casos a análise é mais investida que o analista. É mesmo isto que observo em Clara, quando esta me oferece uma grande riqueza de representações que contrasta com a pouca mudança em sua vida, principalmente no plano afetivo.

A busca do sentido perdido, tal como vemos em Clara, se traduz como busca intelectual, que visa reassegurar o narcisismo intelectual, pretendendo, dessa forma, seduzir o analista, provocando sua admiração. Mas se o afeto se manifesta, é o “desespero que aparece em toda sua nudez” (Green, 1980, p. 270). $\mathrm{O}$ desespero de Clara se revela mais explicitamente nas idéias de suicídio.

Green nos adverte sobre o uso de silêncio junto a esses pacientes (que interessante!): seria equivalente a repetir, na transferência, a relação com a mãe morta. Prefere então uma segunda opção técnica, aquela que,

... utilizando o quadro como espaço transicional, faz do analista um objeto sempre vivo, interessado, e testemunhando sua vitalidade pelos laços associativos que comunica ao analisando sem nunca sair da neutralidade. Pois a capacidade de suportar a desilusão dependerá da forma como o analisando se sentirá narcisicamente investido pelo analista. (Ibid., p. 271)

A análise deveria devolver a vida... Onde então naufragou minha tentativa junto à Clara - se é verdade que meu movimento se dava no sentido de investila narcisicamente, mostrando-me sempre "viva e interessada"? Será que a desilusão de Clara foi tamanha, a ponto de impedir o florescimento da esperança e da crença na mudança?

\section{Narcisismo de vida/narcisismo de morte}

Quando as condições são favoráveis à separação mãe-criança, o objeto materno dá lugar aos investimentos próprios ao Eu, fundadores de seu narcisismo pessoal. O Eu passa a investir seus próprios objetos. Green chama esse narcisismo de primário positivo - ligado a Eros, tendendo para a unidade e a identidade. $\mathrm{O}$ narcisismo negativo não se manifesta pelo ódio ao objeto, mas pelo sentimento do vazio.

No "complexo da mãe morta", o eu, em vez de fazer novos investimentos, confundido com o objeto primário, luta para retê-lo, revivendo repetitivamente sua perda. O resultado é o sentimento de vazio, reflexo de uma ferida narcísica. Aqui é possível compreender as auto-recriminações de Clara. Desconectada das 


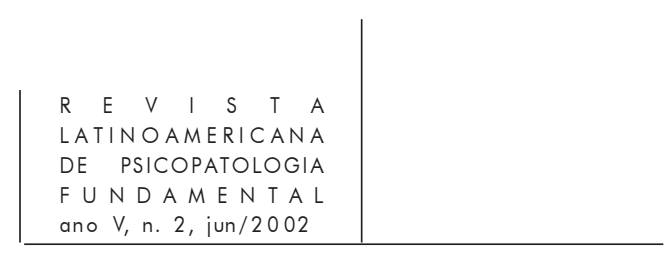

partes (o que Green chama de narcisismo de morte) de seu self, não pode entrar em contato com sua criatividade. Confundido com o próprio trauma, o passado ocupa o lugar de viver o presente de forma significativa.

\section{$M$ de mãe e de morte}

Um dia meu filho Júlio me perguntou: "Mamãe, o que é pior: ficar triste ou ficar doente?". A ressonância de sua pergunta em mim foi intensa. Pensei na condição humana: "nascemos escuro", como diz Drummond, e erramos entre o medo da dor psíquica e da dor física. O entrelaçado das duas dores remeteu-me à situação de Clara; como se ela não encontrasse abrigo, jamais repousando, apenas percorrendo dolorosos e viciados caminhos entre um e outro sofrimento.

Há dezesseis anos que Clara sobrevivia ao câncer, mas eram dezesseis anos em que ela não se distraía da morte. O sofrimento de Clara vindo da infância encontrava-se com o sofrimento da morte anunciada - pororoca maldita! Eram duas grandes dores que se sobrepunham.

Se suas dúvidas de amor já lhe roubaram o precioso sentimento de "pertencer", o que se apresentava mais além - no horizonte de sua morte anunciada - era um radical despertencimento. Se não pertencer visava manter sua autosuficiência, não seria este o preço pago para manter-se viva?

Em sua volta de Nova Iorque, Clara me trouxera um marcador de livros, folheado a ouro, e o formato de um M. Quando o recebi, disse pra ela: M de mãe.

M de mãe ou de morte?

Agora eu digo: $M$ de mãe e de morte. Se eu não falara nem pensara em $\mathrm{M}$ de morte é porque este era um de nossos não ditos. Falávamos da doença, mas não da morte... Talvez porque ambas não suportássemos essa possibilidade. Talvez porque ainda não fosse o momento...

Quanto mais nos aprofundávamos, maior a angústia de Clara e maior o seu desespero em adiar o confronto com o gelo - da morte e da mãe. Eram dois horizontes de horror superpostos: a morte e a mãe gelada. O início e o fim se tocavam...

Se tivesse tempo e confiança, teria sido possível olharmos dentro desse horror? Terei deixado de ouvir Clara em seus sentimentos sobre seu morrer e sua morte? Poderia eu tê-la ajudado a viver sua vida (e sua morte) de outra forma ${ }^{13}$

13. De Winnicott: “Oh, Deus! Possa eu estar vivo quando morrer!”. 


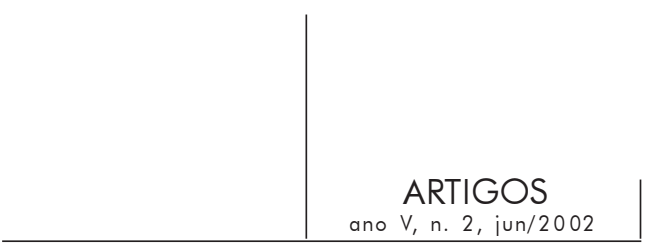

O processo de escrita desse texto foi semelhante à minha história com Clara. Insisti ${ }^{14}$ - é a terceira vez que relato o caso - apostando numa riqueza talvez mais suspeitada do que explícita. Também com Clara eu insisti, porque sabia de sua riqueza - ela me mostrava, mas logo a ocultava. "Não podia dar nada de sua generosidade", como diz Green. Não foi à toa que me surpreendi e me emocionei com o marcador de livros (embora fosse um presente de valor relativo e ambíguo: folheado a ouro, mas apenas um marcador...).

Assim, nossa relação teve também uma dimensão gelada: "Eu gosto de você, você é bacana" - mas isso não mudava nada! Não teria vivido algo semelhante com a mãe (de modo contrário) - quando a via como alguém que tinha o que dar, mas se negava?

Não foram poucas as vezes que me emocionei com Clara. Esta chorava, mostrando-me seu desespero e eu ficava muito comovida com tanta dor e revelações pungentes. Nesses momentos, o gelo derretia e o afeto aparecia - o calor aquecendo nossos corações. Mas toda aquela preciosa emoção, em vez de conectá-la com suas potencialidades, de propiciar-lhe uma experiência transformadora, parecia apenas alargar a ferida que ela acreditava sem remédio. Outra Clara - habitante de um desértico lugar - me surpreendia com a pergunta: "E daí? O que faço com isso?". Por enquanto, era apenas dentro de mim que as duas Claras se reconciliavam: o choro de uma derretendo o gelo do coração da outra. ${ }^{15} \mathrm{O}$ gelo do abandono fere, queima.

Pensando bem, não vivemos uma história de desencontros, como eu disse no início do texto, mas de encontros e despedidas... Filho). ${ }^{16}$

"Quem escreverá a história do que poderia ter sido?" (Armando Freitas

\section{Referências}

AnZieu, D. (1985). O eu-pele. São Paulo: Casa do Psicólogo, 1988.

Barros, M. Livro sobre nada. Rio de Janeiro: Record, 1996.

Bollas, C. (1987). O objeto transformacional. In: A sombra do objeto. Rio de Janeiro: Imago, 1992.

14. Quais os limites entre a insistência e a perseverança?

15. Quem conhece o conto infantil "A rainha da neve"? Considero-o uma singela metáfora do aprisionamento da criança pela depressão da mãe.

16. Citado em Khel, Maria Rita (1996). A mínima diferença. Rio de Janeiro: Imago. 


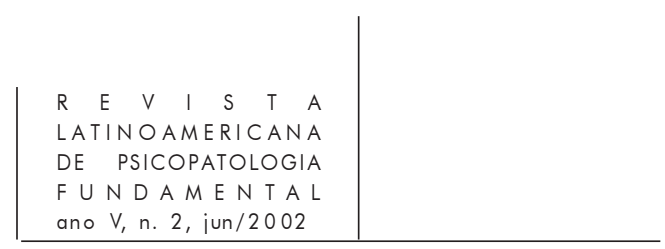

DiAs, E. O. (1993). A regressão à dependência e o uso terapêutico da falha do analista. Percurso Revista de Psicanálise. São Paulo, Instituto Sedes Sapientiae, ano VII, n. 13, 1994.

FÉdidA, P. (1981). Amor e morte na transferência. In: Clínica psicanalítica: Estudos. São Paulo: Escuta, 1988.

Ferenczi, S. (1931). Análise de crianças com adultos. In: Escritos Psicanalíticos 19091933. Rio de Janeiro: Taurus, 1983.

Figueiredo, L. C. Escutar, recordar, dizer. Encontros heideggerianos com a clínica psicanalítica. São Paulo: Escuta/Educ, 1994.

GreEn, A. (1980). A mãe morta. In: Narcisismo de vida, narcisismo de morte. São Paulo: Escuta, 1988.

Conferências Brasileiras de André Green. Metapsicologia dos Limites. Rio de Janeiro: Imago, 1986.

O outro e a experiência de self (prefácio). In: Khan, M. Psicanálise: teoria técnica e casos clínicos. Rio de Janeiro: Francisco Alves, 1974.

Hılst, H. Poesia. São Paulo: Edições Quíron, 1980.

KanaAn, D. A. Comunicação por escrito, 1997.

KeHL, M. R. A mínima diferença. Rio de Janeiro: Imago: 1996.

Little, M. Ansiedades psicóticas e prevenção. Registro pessoal de uma análise com Winnicott. Rio de Janeiro: Imago, 1992.

Pound, E. Poesia. São Paulo: Hucitec, 1985.

Prado, A. Poesia reunida. São Paulo: Siciliano, 1991.

SAfra, G. Algumas necessidades psíquicas básicas. In: Momentos mutativos em psicanálise. São Paulo: Casa do Psicólogo, 1995.

Stein, C. (1987). As Eríneas de uma mãe: ensaio sobre o ódio. São Paulo: Escuta, 1988.

WinnicotT, D. W. (1967). O papel de espelho da mãe e da família no desenvolvimento infantil. In: O brincar e a realidade. Rio de Janeiro: Imago, 1975.

(1963a). Distúrbios psiquiátricos e processo de maturação infantil. In: $O$ ambiente e os processos de maturação. Porto Alegre: Artes Médicas, 1982.

(1963b). Dependência no cuidado do lactente, no cuidado da criança e na situação psicanalítica. In: $O$ ambiente e os processos de maturação, op. cit. (1963c). Comunicação e falta de comunicação levando ao estudo de certos opostos. In: Explorações psicanalíticas. Porto Alegre: Artes Médicas, 1994.

(1964). Transtorno psicossomático. In: Explorações psicanalíticas, op. cit. (1954-5). Aspectos clínicos e metapsicológicos da regressão dentro do setting psicanalítico. In: Textos selecionados da pediatria à psicanálise. Rio de Janeiro: Francisco Alves, 1993. 
El presente artículo relata la historia de una consulta (con sus encuentros y desencuentros) de una paciente llamada Clara, que padecía intensos dolores relacionados tanto a un cáncer del cual era portadora como a los "fantasmas" que "arrastraba desde su infancia".

La interrogación sobre la técnica como modo "necesario y justo" de aproximarse al sufrimiento y promover cambios atraviesa todo el texto.

Palabras clave: depresión materna, narcisismo de muerte, transferencia, técnica

Le présent article présente l'histoire clinique (ses rencontres et malentendus) d'une patiente appellée Clara. Cette histoire clinique inclue les douleurs profondes dues au cancer de cette patiente et aux "fantasmes" qu elle traîne avec elle depuis l'enfance.

L'interrogation sur la technique, comme modalité nécessaire et juste de s'approcher de la souffrance et promouvoir un changement, parcours tout le texte.

Mots clés: Dépression maternelle, narcissisme de mort, transfert, technique

The present article summarizes the history of the treatment (encounters and nonencounters) of a patient named Clara suffering from intense pain caused by cancer and by the "ghosts" she has been bearing since childhood.

The question as to the technique as a necessary and just way to come closer to the patient's suffering and to promote changes can be seen throughout the text.

Key words: Depression in motherhood, narcissism of death, transference, technique

Versão inicial recebida em junho de 2001

Aprovado para publicação em março de 2002 